\title{
Collapsing Stakeholder Groups: Insights Into Professional Sports Organizations And Competitive Positioning
}

Dana V. Tesone, (Email: dtesone@mail.ucf.edu), University of Central Florida Alan Platt, (Email: arplatt@fcgcu.edu), Florida Gulf Coast University

George Alexakis, (Email: alexakis@nova.edu), Nova Southeastern University

\begin{abstract}
The article investigates the force field stakeholder structure of National Football League (NFL) sport organizations relative to those that provide the domain that governs the management of other medium to large commercial entities. Textual and visual images of the affiliations among the various NFL organizations' stakeholder groups in the manuscript provide a framework of the stakeholder force field domain. The model presents comparative and contrasting data relevant to typical business organizations of similar size, expenses, and revenue capacity. Finally, the article identifies managerial practices in NFL organizations and provides explanations for these processes applicable to the force field domain under which they are governed. The authors conclude that managerial practices in NFL organizations are contrary to those adhered to in regular commercial enterprises; however, these managerial practices are appropriate for the particular stakeholder force field domain that governs these particular sport organizations, which fosters "collaborative parity." Future research that delves into areas of major league football's and other leagues' evolving economic constructs as they pertain to stakeholder issues such as controlling labor costs, the relocation of a particular team, and the necessity of increasing the volume of existing and emerging revenue streams is recommended.
\end{abstract}

\section{INTRODUCTION}

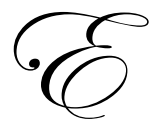

ach stakeholder group in an organization represents a force field of accountability in relation to specific interests of each constituent group that impose both risk and opportunities for leaders of commercial enterprises. Opposing interests between stakeholders generate leadership conflicts, in which the demands of one group are diametrically opposed to the goals of an opposing group (employees versus shareholders, for instance).

The business model of most privately owned and publicly held corporations is considered by some to be complex in nature (Tesone, 2003a). In contrast, the business format of the National Football League is comparatively simple (Tesone, Platt, \& Alexakis, 2003). While the academic literature in business and management is replete with descriptions of traditional business models for corporations, specialized niches of peer-reviewed publications consider those same models in professional sports organizations, in particular the NFL (Kildegaard, 2001; Moore, 2001; Prestegard, 1996; Grier \& Tollison, 1994). Before presenting the eccentricities associated with doing business in the NFL, consideration of what is generally reported in the contemporary business literature provides a model for comparison and can be successfully applied to corporations and other types of organizations.

Management practitioners and scholars are familiar with the traditional business management functions of accounting, sales, marketing, production, etcetera. While in the late 1970's the strategic approach to managing human capital created what is today known as the human resource function; the current implications of technological systems in the overall strategic positioning of organizations are responsible for the development of chief information officer (CIO) positions at the executive level of corporations (Tesone, 2003b). In both of the above cases, the constituent 
groups (or stakeholders) were identified as the essential drivers in modifications to the organizational structure, arrangements, and practices.

While the identification of stakeholder groups varies in the literature, most business scholars agree on a minimum of four primary segments of constituents. They are identified as customers, shareholders, employees, and members of the community (social stakeholders) for typical privately held and publicly traded corporations (Kristenson, 1983; Steadman, 1997; Blair, 1998; Hunger \& Wheelen, 2000; David, 2001). A visual depiction of the four basic groups arranged in a force field model of specific interests is presented in Figure 1.

Figure 1

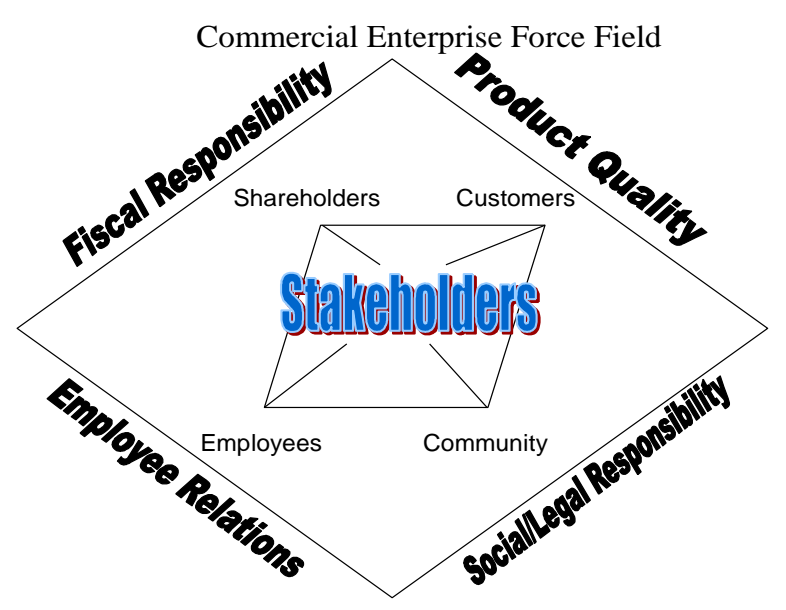

Commonly noted diametric force fields exist between the interests of fiscal return on the part of shareholders (often short-term ROI) as opposed to the social and legal responsibilities demanded by the community group (social and legislative forces). This contrasting force field is the focus of many reports in the area of business ethics (Kelly, 2003). A second diametric field exists between customers who seek product quality and value (adversely influenced by cost of production) and employees who are lured to employment with the organization as the result of attraction and retention strategies via compensation practices and professional supervision (a portion of production costs).

From a customer perspective, employee relations' practices equate into production and distribution costs that influence the pricing of products and services. The fiscal responsibility interests of shareholders may be perceived as being constrained by social mandates and by governmental regulations, particularly in the form of antitrust legislation, environmental regulations, and other practices influencing opportunities for maximum return on investments. In addition to the diametric fields of opposing constituent groups, there are vertical relational fields providing compatible forces of alliance. For instance, the social responsibility field equates into product safety and truth in advertising, which enhances the customer constituencies' perception of product quality. On the other side of the model, employee relations' attracts and retains professional corporate management with the talent to provide profit maximization. Hence, the typical model for corporations provides relationships of both compatibility and contrasting relationships, which results in a holistically balanced force field framework. This may not be the case for organizations within the NFL domain.

The NFL is a tightly held consortium of franchises. With the exception of the Green Bay Packers, they are privately owned entities that retain control of organizational ownership. While communications corporations have been precluded from direct club possession, it is a fact that each franchise and the media exist in symbiotic and interdependent partnerships. Together they are viable informal joint ventures, whereas separately they would not be positioned to benefit from the huge revenue opportunities currently afforded to both industries. The NFL system could 
not survive in its current state without constant print and electronic media coverage. While at the same time, the media organizations are reliant on the vast programming opportunities associated with the NFL. This leads to the question as to the source of these vast revenue streams. The answer to this question brings into play a third stakeholder group that would be identified as "customers" in regular commercial parlance, which are referred to as "fans" among NFL enterprises. Fan support of the NFL franchises is stable and enthusiastic. Figure 2 provides a representation of the stakeholder force field diagram for each organization within the NFL.

Figure 2

NFL Governance Force Field

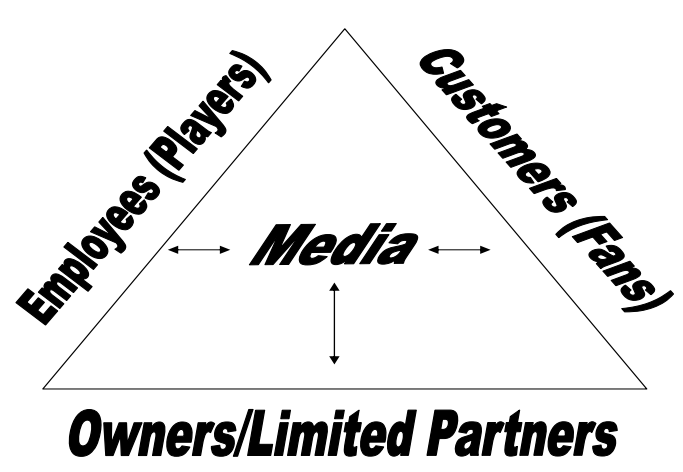

These "customer" loyalty factors are attributable to the opportunity for fans that support any specific club to witness the thrill of NFL action along with the potential to have their team emerge as champions in any given season. Contrary to the belief system of the average fan (customer), this scenario is not by chance. Instead, it is orchestrated through the "cartel mentality" of the 32 franchise owners within the league. In this case, an environment of orchestrated parity among and within membership organizations serves each team owner, the "silent partner" media enterprises, as well as the fans of the sport. This parity creates the illusion of equal competition that motivates the fans to bankroll the revenue streams for every organization represented by the NFL and every media conglomerate fortunate enough to provide coverage of the sporting events. While the model works nicely in the world of sports, other commercial industries would incur the wrath of the social and legal community stakeholder group if it were to attempt to replicate this model. However, there are elements of the NFL paradigm that have organizational applications in other industries.

Franchises in the NFL, National Basketball Association (NBA), National Hockey League (NHL), and Major League Baseball (MLB) are examples of some of the most tightly constructed monopolies in history. Professional sport franchises are a monopoly at the national and international level, because only a select number of organizations sponsor a predetermined number of teams. The U.S. Congress has accepted this monopolistic method of doing business. "This guarantees relatively predictable revenues for team owners and gives them the power to influence television companies and the commentators working for those companies. This is why announcers sound like cheerleaders for the sports their companies pay to broadcast" (Coakley, 2004, p. 385). Although The United States Congress and the courts have sometimes scrutinized several firms, like Microsoft Corporation, they have not acted to stop the single dominant league outcome in professional sports (Fort, 2003).

\section{THE NATIONAL FOOTBALL LEAGUE: A CASE IN POINT}

NFL franchises have been particularly lucrative for those individuals who own them. They are guaranteed a substantial revenue stream and effective leverage for negotiating residual incomes beyond the ticket office. These 
organizations have strict rules to protect their collective interests. Opportunities and freedom in the areas of labor, sales of league related merchandise (licensed products), competition for fans, and media revenues are all regulated to provide barriers to entry and to eliminate competition.

Through the utilization of a player draft, the NFL has developed a system that forces new players to agree to a structure that gives them no opportunity to initially choose their employer. Few other business concerns limit the opportunity for employees to choose where they are employed. Professional sports in the U.S. require new players to be drafted by a franchise and commit to that franchise. New players, unlike free agents, are not afforded the opportunity to seek out the highest bidder. Similarly, new team franchises may not enter the league unless the existing owners (an exclusive cartel) approve their entry. Upon league approval, the entrance costs are enormous. The Cleveland Browns paid approximately $\$ 600$ million and the Houston Texans paid $\$ 800$ million for the right to join the NFL monopoly. These entry fees are divided among the existing franchises (Nethery, 2001).

The revenue generated by media broadcast rights is essential to the NFL's prosperity. The league members have agreed to sell broadcasting rights as a group. They limit the number of games that are televised. They even have strict rules as to whether an already scheduled broadcast may proceed. If, for example, the home team is not sold out, there is an automatic "blackout" covering a 75-mile radius from the stadium. A blackout means that television viewers within the specified range cannot watch the game on television if every ticket is not sold. The rule is remarkable when one considers that in most cases the majority of the funds used to finance the initial construction of the stadium were provided by the public. The only exception to the blackout rule would be in the case where an individual purchased satellite-based programming. In this case, the NFL shares in the profits.

By exempting owners of the four major sport leagues from antitrust laws, the owners can expect another large windfall (Nethery, 2001). While some franchises do not show an operating profit, they do realize major capital gains at the time of sale. The Miami Dolphins were established upon payment of a \$7.5 million franchise fee in 1966. Today this franchise would likely be sold for $\$ 1$ billion. Every franchise in all of the professional leagues has a similar story. Many major league baseball franchises operating on a breakeven basis, or even at a loss, still enjoy major capital gains. The Los Angeles Dodgers moved from Brooklyn, New York in 1958 for a \$2.1 million franchise fee and were sold to Rupert Murdoch in 1998 for $\$ 311$ million. In October of 2003, the Dodger franchise reached a sales agreement with Frank McCourt for approximately $\$ 430$ million (Madkour, 2003). Jack Kent Cooke paid \$300,000 for a 25\% interest in the Washington Redskins NFL team in the early 1960's. Daniel Snyder, paid $\$ 800$ million for the franchise and the stadium in 2000. Arthur Blank, the founder of Home Depot, paid \$545 million for the Atlanta Falcons in 2002. He purchased the franchise from Rankin M. Smith, Sr. who paid \$8.5 million in 1965. The Falcons are near the bottom in NFL attendance (Nethery, 2001).

Since 1990, 76 new facilities have been built for the four major professional sports leagues. The owners of the teams do not pay for the full cost of these buildings. In fact, $\$ 10.4$ Billion in public funds have been spent versus $\$ 7.6$ Billion in private money (Madkour, 2003). A small number of wealthy individuals have devised a method to have the general population provide them with the physical plant necessary to conduct business. A system of "stadium socialism" has provided unbelievable opportunities for owners to use vast sums of public funds for their personal profit. These sports leagues have sold the idea that if a city is to be considered "world class," then they must have a viable professional sport franchise. The owners make a simple proposition, build my franchise a stadium or the team will relocate. Art Modell, owner of the Baltimore Ravens (formerly the Cleveland Browns) perfected the tactic of public subsidy for private consumption. When Cleveland was slow to respond to his demand to build a new stadium, he moved the franchise to Baltimore. The city of Baltimore funded a new stadium at the expense of the local taxpayers. There was virtually no cost to Modell for the move. He even negotiated that all income derived from the stadium will remain with the franchise. At the same time these negotiations were occurring, the Baltimore Public Schools could neither pay to heat their buildings nor could they purchase bathroom tissue for their restrooms (Brady, 1996).

The tax-exempt bond is the favorite financing vehicle for professional owners looking for government funding. The nonpartisan Congressional Research Service provided data to members of the U.S. Senate on the method. One senator stated that the use of these bonds "mounts to little more than a public housing program for millionaire team owners and their millionaire employees [athletes]" (Welch, 1996). One senator also asked, "Do we 
have enough money to finance stadiums for team owners at the same time we are cutting Head Start Programs?" (Brady \& Howlett, 1996)

\section{WHY THE MODEL WORKS}

As opposed to the standard business enterprise model, which is four-dimensional, the NFL model contains only three forces around its perimeter. The balancing factor in the model is an external source (the media) that is internalized by all stakeholders due to its value to each individual constituent group. Dual arrows indicate mutual reliance between the media and each governing force of an NFL franchise. Hence, the media is the focal point of balance among all the stakeholders, which is an exact model of parity. The odd number of stakeholder groups precludes equal alliances and disparities. In a three-dimensional model, two groups overpower any single constituency during an attempt at dispersive disruption. For instance, a labor strike on the part of NFL players will incur the wrath of not just the owners but also the fans that are customers in this case. This may help to explain rapid rates of resolution in labor disputes in the NFL relative to protracted disruptions in other commercial enterprises. This is not to suggest the absence of greed on the part of any single constituency, which historically is the cause of government regulation creating the fourth dimension in commerce over time. In the NFL, the media provides the fans (customers) with mitigating alternatives to issues such as outrageous ticket prices through broadcast options. This may explain why less than one percent of total football fans have ever attended a live NFL game (Nethery, 2001).

\section{IMPLICATIONS FOR OTHER COMMERCIAL ENTERPRISES}

As a precursor to subsequent articles, the following is an analysis of the useful application of the above issues. Obviously, the NFL and the other professional sport leagues have some significant built-in advantages and the specific ways that the franchisers and franchisees maximize these rewards. Although professional sport franchises are dissimilar to other businesses in a myriad of ways, the model previously illustrated and discussed has an important and interesting link to organizations in other industries; it is called "fanatical customer loyalty." It is relatively self-evident that the loyal fan is the major underlying factor that has permitted so many concessions to be given to professional teams by the U.S. society (Tesone, Alexakis, \& Platt, 2004).

The passionate nature of fans towards their teams is rarely seen among customers outside professional sports. There is fierce customer loyalty for a handful of corporate firms, such as Apple computers, Saturn cars, and Harley Davidson motorcycles. However, the four professional leagues in the U.S. also have industry-wide allegiances and hence enjoy "cradle to the grave" customers. Understanding the emotional factors that create such intense customer loyalty in professional sports would be of significant value to traditional corporations and other organizations.

\section{CONCLUSION}

In light of the above discussion, the typical U.S. commercial enterprise must recognize that it is the all the fans that maintain the NFL monopoly, which causes each team to ultimately succeed financially. It is useful to not focus on the contrary argument that suggests that teams are successful because they are a part of a monopoly. Nonetheless, the current business model of the NFL is a comparatively failsafe investment for each participating organization. The total league revenues for 2002 were $\$ 4.8$ billion with $\$ 3$ billion equally divided among the teams (63\%). Each team gets $\$ 78$ million share from the network and cable television contract split, as well as $\$ 10.9$ million from the visitors share on ticket revenue and $\$ 6.2$ million from their Direct-TV split, merchandise sales, and league sponsorships. Each team, therefore, receives a guaranteed $\$ 95$ million in revenues. Over the next calendar year, they must spend a between a maximum of $\$ 83$ million and a minimum of $\$ 80$ million on player's salaries and benefits (Lowry, 2003). Other, non-guaranteed income is derived from local sponsorships, luxury suites, broadcasting, parking, and concessions. These revenue streams are retained by the local franchise and can be large. A total of $\$ 1$ billion was derived from the league in these areas.

While the majority of industries are comprised of business enterprises that engage in "open competition" commercial activities, the NFL clearly operates within a framework of "collaborative competition" between each of its membership organizations. The essential driver for commercial industries is a four-way force field of disparate and 
alliance constituencies. This is in contrast to the three-field model evident in the structure of the NFL, which is designed for total parity among all constituent groups. Clearly, the NFL model is mutually beneficial to all stakeholder groups and has demonstrated immensely successful outcomes resulting from a parity-based governing domain. In contrast, the social and legal community consistency that governs other capitalistic endeavors in the United States would find such a model to be harmful to society. However, in the world of sports the government (including Congress) comprises just another group of fans.

\section{SUGGESTIONS FOR FUTURE RESEARCH}

The economics of future professional sports can be better understood from a business perspective through more carefully examining National Football League's intricate economic setups and arrangements among its various stakeholders. On March 28-31, 2004 in Palm Beach, Florida, the NFL held its annual meeting, where the fate of the master agreement was decided. The owners approved by a 26 to 3 vote, with three abstentions, to extend the agreement for another 15 years. The outcomes of the agreement will provide further opportunities for analysis of NFL's evolving business plan and will allow researchers to view the NFL as a case study in the economics of business systems. Close inspection of the agreement can inevitably lead to the issues of controlling labor costs and the necessity of increasing the volume of existing and emerging revenue streams.

In addition, research that further contrasts the standard operating practices of the four established major sport leagues and traditional American corporate organizations is likely to elicit an interest among academicians. Operating practices should include discussion on the strength of the player's unions followed by distinctions surrounding the expanding benefit packages of professional players and the decreasing benefit packages of corporate American workers. Of particular interest for future study is the NHL lockout and the force field implications between players, customers, and owners. Force field research is also warrented concerning the relocation of the former Montreal Expos. Finally, the cause of fervent customer devotion to an industry like professional sports would be of significant value to traditional corporations. An examination of the underlying factors is a topic for future applied research.

\section{REFERENCES}

1. Blair, J.D. (spring, 1998). "Competitive forces in the medical group industry: A stakeholder perspective". Health Care Management Review. Frederick. 23, (2). 7-29.

2. Brady, E. (September 6, 1996). "Ballpark construction's booming Cost to hit $\$ 9$ billion by decade's end, but who's paying for it?" USA Today. Washington, DC 13C.

3. Coakley, J. (2004). Sports in society: Issues \& controversies $\left(8^{\text {th }}\right.$ ed.). McGraw Hill: New York.

4. Brady, E. \& Howlett, D. (September, 1996). "Who's paying for ballpark binge? Your taxes will build 45 new facilities". Seattle Times. Seattle D5.

5. David, F.R. (2001). Strategic management: Concepts and cases $\left(8^{\text {th }}\right.$ ed.). Prentice Hall: Upper Saddle River.

6. $\quad$ Fort, R.D. (2003). Sports economics. Prentice Hall: Upper Saddle River.

7. Grier, K.B. \& Tollison, R.D. (October, 1994). "The rookie draft and competitive balance: The case of professional football”. Journal of Economic Behavior \& Organization. Amsterdam. 23, (2). 293-300.

8. Hunger, J.D. \& Wheelen, T.L. (2000). Strategic management and business policy: Entering $21^{\text {st }}$ century global society $\left(7^{\text {th }}\right.$ ed.). Prentice Hall: Upper Saddle River.

9. Kaplan, D. (February, 2004). Divide on revenue sharing persists in NFL Trust debate. 6, (43). 1.

10. Kelly, H.F. (Jan/Feb, 2003). "2003 preview: Maintaining the balance". Commercial Investment Real Estate Journal. Chicago. 22, (1). 24-26.

11. Kildegaard, A. (May, 2001). "A note on "single-entity" and promotional incentives in MLS". Journal of Sport and Social Issues. Thousand Oaks. 25, (2). 216-212.

12. Kristenson, L. (1983). "Strategic Planning in Retailing". European Journal of Marketing. Bradford. 17, (2). 43-52.

13. Lowry, T. (January, 2003). "The NFL machine". BusinessWeek. McGraw-Hill.

14. Madkour, A. (December, 2003). "By the numbers: Facilities". Sports Business Journal. 6, (36). 49-72.

15. Moore, M.E. (2001). "Women in sport management: Advancing the representation through HRM structures". Women in Management Review. Bradford. 16, (2). 51-55. 
16. Nethery, R. (December, 2001). "By the numbers: Football”. Sports Business Journal. 4, (37). 86-105.

17. Prestegard, S. (May, 1996). "His business is football". Marketplace Magazine. Appleton. 7, (9). 12-40.

18. Steadman, M.E. (1997). "An extension of stakeholder theory research: Developing surrogates for net organizational capital”. Managerial Auditing Journal. Bradford. 12, (3). 142-151.

19. Tesone, D.V., Alexakis, G., \& Platt, A. (summer, 2004). "The human capital factor: Successfully meeting managerial challenges in business and sport management". Journal of Applied Management and Entrepreneurship 9, (3) 22-33.

20. Tesone, D.V., Platt, A. \& Alexakis, G. (fall, 2004). "The five mythical habits of highly ineffective leadership: The anecdote is the antidote in the games professionals play". Journal of Human Resources in Hospitality 2, (1) 1-15.

21. Tesone, D.V. (2003a). Tactical strategies for service industry management: How to do it. Pearson-Prentice Hall: Boston.

22. Tesone, D.V. (2003b). Management and technology for the hospitality industry: Higher tech for higher touch. Pearson-Prentice Hall: Boston.

23. Welch, J. (August, 1996). "Have clubs, will travel”. Louisville. Louisville. 47, (8). 29-36. 
NOTES 